DOI: 10.1515/ausfm-2017-0007

\title{
Film and Media as a Site for Memory in Contemporary Art
}

\author{
Domingo Martinez Rosario \\ Universidad Nebrija (Madrid, Spain) \\ E-mail: dmartinezr@nebrija.es
}

\begin{abstract}
This article explores the relationship between film, contemporary art and cultural memory. It aims to set out an overview of the use of film and media in artworks dealing with memory, history and the past. In recent decades, film and media projections have become some of the most common mediums employed in art installations, multi-screen artworks, sculptures, multi-media art, as well as many other forms of contemporary art. In order to examine the links between film, contemporary art and memory, I will firstly take a brief look at cultural memory and, secondly, I will set out an overview of some pieces of art that utilize film and video to elucidate historical and mnemonic accounts. Thirdly, I will consider the specific features and challenges of film and media that make them an effective repository in art to represent memory. I will consider the work of artists like Tacita Dean, Krzysztof Wodiczko and Jane and Louise Wilson, whose art is heavily influenced and inspired by concepts of memory, history, nostalgia and melancholy. These artists provide examples of the use of film in art, and they have established contemporary art as a site for memory.
\end{abstract}

Keywords: contemporary art, cultural memory, memory, film, temporality.

\section{Introduction}

Film and video have become two of the most common disciplines of contemporary art in recent decades. Though the traditional setting of the cinema is still used to display contemporary film and video artwork, new presentation possibilities both inside and outside the exhibition room have been explored. Installations, multi-screen artworks, sculpture and multi-media art are the main art forms in which film and media projections have been given shape. At the same time, film and media have been used to tackle a wide range of themes in art, such as identity, post-colonialism, globalization, history, contemporaneity (time, place, mediation, ethics), etc. Memory is also a major theme, since a large number of 
artists deal with the way in which we read, conceive and understand the past and history in accordance with the circumstances of the present.

This article explores the relationship between film, contemporary art and cultural memory. ${ }^{1}$ I will set out an overview of the use of film and media in artworks dealing with memory, history and the past. This argument will aim to elucidate the main features of film and media that deal with the past and trigger a memory work in the viewer. In order to do this, I will firstly approach the field of cultural memory and, secondly, I will set out an overview of some pieces of art that utilize film and media to deal with historical and mnemonic accounts. Lastly, I will consider the specific features and challenges of film and media that make them an effective repository for art to represent memory.

\section{Memory Studies and Contemporary Art}

Memory studies ${ }^{2}$ is a multi-disciplinary and interdisciplinary field of studies that considers the processes by which collective memory is shaped in different cultures. It also tackles the ways, in which societies institutionalize collective memory through commemorations of the past in museums, festivals, art, film and so on, and the part played by these activities in producing various forms of social and cultural identity.

The field of memory studies draws on and addresses a considerable variety of disciplines: psychology, literary studies, history, art history, art, sociology, cultural and media studies, film studies and more.

Memory studies have become a central topic in History and Cultural Studies, ${ }^{3}$ and memory is now considered as an exclusive phenomenon of the present. Memory is now understood as the perception of the past and is in continuous transformation due to the fact that it is dependent on the conditions of the present

1 The notion of cultural memory was introduced by the German Egyptologist Jan Assmann in his book Das Kulturelle Gedächtnis (1992) and it gives name to the field of memory that addresses the past in relation to the present. Assmann proposes this term based on Maurice Halbwachs's notion on collective memory, which is carefully analysed in his book La Mémoire collective (1950).

2 In 2008, an academic journal was released for the first time under the title Memory Studies. It documents the wide-ranging considerations and debates about the theoretical, empirical and methodological concerns that form such a field of study. According to the statement in the journal website, "Memory Studies examines the social, cultural, cognitive, political and technological shifts affecting how, what and why individuals, groups and societies remember, and forget." (See: http://mss.sagepub.com).

3 Jan Assmann (1992), is one of the most influential writers that have tackled history and the past from the perspective of the present. But there are other writers such as Michel Foucault (1977) and Andreas Huyssen (1995) who have not only tackled history through mnemonic accounts, but also have considered the impact of memory on Cultural Studies. 
and is constructed under current circumstances. Such issues have had an impact on cinema, literature and documentary practice, and have grown in relevance in relation to the field of contemporary art.

Especially over the past two decades, the relationship between art and memory has been the object of increasing academic attention, ${ }^{4}$ with growing interest in film and cinema as repositories for representing, shaping, re-creating or indexing forms of individual and collective memory. Consequently, contemporary art has become a medium within which to hold current discussions and debates about memory, giving shape to different platforms of memory that resonate with artistic practice.

\section{Film and Media in Contemporary Art}

It is worth bearing in mind that there has always been a connection between film and memory. In recent decades, film, media and communication studies are fields that are growing in importance within the discipline of memory studies, according to Anamaria Dutceac Segesten and Jenny Wüstenberg's recent survey of the state of memory studies $(2016,9)$. This is mainly due to the fact that collective memory has been significantly informed by mass media and cinema over the past century.

It is also worth considering that the relationship between cinema and memory can operate at several levels. (Landsberg 1995, 176.) For instance, cinema memory (the memories of the social activity of going to the cinema) can be considered as a part of cultural or collective memory. Film can tackle the past, historical events or even bring to mind forgotten or repressed accounts of history, rising cultural memory in that way.

Film language is a particularly efficient method of evoking memory, especially by its ability to represent mood and subjective emotions. As a matter of fact, cinema works as a platform or repository for memory. The expansion of studies examining the links between cinema and memory has been remarkable since the 1990s, along with the rise of debates and questions of memory across a wide range of disciplines. The principle themes relating to memory that have been explored in cinema are: cinema and place; cinema, culture and identity; and film, film shows and stars.

Therefore, film can be understood as a site or storage for memory, like other storage mediums that have been used in society, such as analogue amateur

$4 \quad$ The upsurge in contemporary artists dealing with memory and history has led art critics and academics to analyse artistic strategies to deal with memory. Some of the key names are Joan Gibbons (Contemporary Art and Memory: Images of Recollection and Remembrance, 2006) and Lisa Saltzman (Making Memory Matter: Strategies of Remembrance in Contemporary Art, 2006). 
photographs and home movies. Contemporary artists dealing with memory have found fruitful material in these mediums to produce their works.

Using such material, artists aim to revise or reassert historical events and epochs of social change, as well as the ways in which people record and pass on their memories. These processes often involve the digitization of analogue mediums and result in final artworks comprising videos, photographs, video installations, image projections or online archives. A range of strategies has been developed to deal with memory and history in art, which has reconfigured art practice and works of memory in general.

\section{Common Strategies in the Use of Film in Contemporary Art}

In order to analyse and frame the use of film in contemporary art dealing with memory, I argue that there are three principle strategies used by artists working in the field.

The first one is the appropriation of found and discarded objects or films. Artists use amateur photographs, home movies, old films and other objects due to their power to trigger emotions, nostalgia and melancholy, engage the viewers' attention and involve them in the artwork. The second strategy is a critical reconsideration of the past, i.e. history. Memory is understood not as fixed accounts of the past, but as something that is influenced by contemporary circumstances and emotions. In this way, memory becomes a tool for revising past and historical events and also for helping to understand the present. The third strategy draws on the representation of temporality and time in the artwork. Artists generally employ images and films that embody different times in the past. By doing this, artists echo the way in which memory works; it evokes different events in the past in a non-lineal sequence. They construct a type of narrative that is made up of fragments. In order to explain such artistic strategies, I will consider the work of internationally renowned artists like Tacita Dean, Krzysztof Wodiczko and Jane and Louise Wilson, whose art is heavily influenced and inspired by notions of memory, history, nostalgia and melancholy. These artists set a clear example of the use of film and home movies in art, and also establish contemporary art as a site for memory. 


\section{Tacita Dean and the Appropriation of Old Objects and Films}

Visual artist Tacita Dean is one of the so-called Young British Artists. Her artworks comprise films, drawings, photographs, audio tracks and installations. She examines the links between different events that take place in diverse times and places, building up narratives that act as a meeting point for the past and present, fact and fiction, individual stories and greater events.

Dean uses banal objects and films to explore essential themes in life, death, history and memory. Her work is based on historical and autobiographical investigations. Among all the artistic disciplines that Dean uses in her works, $16 \mathrm{~mm}$ film is maybe the one that defines her art production, as she is very interested in the medium's formal features. Since her early work, her amateur photographs and films have explored the border between fact and fiction, but also past and present times. For Dean, an image or a casual encounter with any past remnant becomes a mnemonic palimpsest.

Some of her major pieces belong to a project that tells the story of an amateur yachtsman called Donald Crowhurst. The film artworks in this project are Disappearance at Sea (1996), Bubble House (1999) and Teignmouth Electron (2000). Crowhurst participated in a round-the-world yacht-race in 1968, but his boat went adrift and he died. While sailing, Crowhurst recorded $16 \mathrm{~mm}$ films and wrote an on-board diary, which Tacita Dean used in her work. After getting lost in the middle of the Atlantic Ocean, Crowhurst realized he would not survive for longer than a day in the area of strong wind and would not be able to finish his journey around the world. In spite of the tough situation, he started faking his journey in his notebook writings and on the radio messages he sent. Eventually, Crowhurst lost track of his location and orientation in the ocean and all references of time, and so decided to commit suicide by jumping from the boat.

Dean has associated this event with something that happened shortly afterwards. On the $20^{\text {th }}$ of July 1969, ten days after the boat was found in the middle of the ocean, the Apollo 8 landed on the Moon. This coincidence makes the catastrophe of Crowhurst work "as an allegory of transition to a new regime of historicity" (Royoux-Warner-Greer 2006, 89). In this way, the story of a specific person is not as important for Dean as the allegorical power for marking the time of a historical change. In other words, "what is allegorically shown in the films of Disappearance at Sea is not that much the disappearance of the yachtsman, but 
what the world will be like if time would be fully absorbed by space, and the past fully absorbed by the present" (Royoux-Warner-Greer 2006, 89).

Teignmouth Electron (2000) is part of the investigation of the Donald Crowhurst story, which took Dean to Cayman Bra Island, where Crowhurst's abandoned boat was found washed up on the shore. Both in this film about the boat and in Bubble House (a film about an abandoned house that Dean found on the same island), the void, the flooding and the structures of ruins are the central points of interest. The way in which Dean records the void and discarded objects emphasizes their sculptural nature, specifically by employing slow and still shots to explore the surfaces, textures and the opening in the wall that connects the space outside the house. According to Tamara Trodd, "Dean utilises the sea as a rich metaphoric link to shape the action of time over objects, and also as a system to preserve and transform objects, their losses and the occasional returns, rich and strange swelling, full of corals and calcified."

Dean records discarded objects and ruins on analogue media not only to depict the memories, nostalgia and past experiences that objects and ruins recall, but also because analogue media itself is a symbol of the failure of future expectations and hopes that didn't come true and it helps us understand our current time. In this sense, Dean's films stand as the ultimate platform to hold historical time and also a figurative time that contrasts with the passing time of the film itself. The use of temporality to depict the past is a key strategy in these films. The juxtaposition of several temporalities in the same film succeeds in recalling past events and revising them, as well as their accounts or stories that are now presented as appropriated fragments. From a symbolic point of view, objects and places are located in "a hypothetic and fictitious version of an undated future, that never happened and about which time has been constructed in a strange way" (Trodd 2008, 384).

The post-Duchamp strategy of choosing allegorical elements, commonly known as ready-mades, ${ }^{5}$ is a relevant feature in Dean's artistic production, and it actually provides key guidelines to understand our current world. In this way, Dean produces elements and objects of historical reference that are articulated, represented and reviewed with the purpose of comprehending the changes and standards that define present time.

$5 \quad$ Ready-made is the artistic strategy that Marcel Duchamp coined in 1967 with his work Fountain. Ready-mades are completely unaltered everyday or found objects selected by the artist and designated as art. Such objects are considered as art due to the designation placed upon them by the artist and the social history that comes with the object. 


\section{Krzysztof Wodiczko and the Critical Reconsideration of the Past}

Polish artist Krzysztof Wodiczko has projected images onto buildings and monuments since the 1980s, creating a space for recollection. The projections have been seen in cities such as Krakow, Hiroshima, London, Berlin, Madrid and Boston. Combining the history of monumental architecture and video projections, an ideal medium for registering and broadcasting testimony is formed. The images projected are often human faces and hands that encourage the viewer to look and listen; we can hear them recounting memories and personal experiences of certain events. In doing so, stories that are normally kept in private are put on public record.

Wodiczko focuses on the way in which architecture and monuments depict historical and collective memory, which is considered and paired with the stories and images projected on them. All his artworks combine ways of passing on oral history with video media in his aim to give voice to the victims.

In his installation in Hiroshima, images are projected onto the Genbaku dome, the well-known building partly destroyed by the atomic bomb, which is currently the Hiroshima Peace Memorial. As the images are projected, the voices of the victims and survivors from the devastating bombing are both summoned and represented. Wodiczko not only returns the memories of the event to the audience, but he also encourages the retrieval of personal traumatic stories in the viewers' own memory.

By using monuments and public buildings as the "screen" for his film and video projections, Wodiczko draws attention to the collective and historical memory embodied in architecture and monuments, which are now questioned by the images projected on them. Especially since the 1990s, the artist has started adding sound to the images and cooperating with the communities that are represented in the films. In this way, Wodiczko provides a direct testimony of marginalized and excluded citizens, who actually live close to the monuments, but are not part of the history represented on them.

There have been more than eighty public projections made around the world (in Australia, Canada, England, Germany, Ireland, Israel, Japan, Spain, Poland and the USA), each tackling topics that have concerned the artist over his forty-year-long career: war, conflict, trauma, memory and communication in the public realm.

Wodiczko names his work as "interrogative design" because they refer to the aesthetic practice that impacts on reality by considering the citizens' life 
situation and the institutional buildings in the city. These films are not about designing something that directly solves problems or addresses a societal need, but something that makes people aware of their collective history and that brings to light certain difficulties in society. In Wodiczko's own words, “design as a research proposal and implementation can be called interrogative when it takes a risk, explores, articulates, and responds to the questionable conditions of life in today's world, and does so in a questioning manner. Interrogative design questions the very world of needs of which it is born" $(1999,16)$.

The work Bunker Hill Monument Projection (1998) is a clear example of Wodiczko's projections, in which film images, sound and victims' accounts merge. They question the message of the monument and outline the importance of the viewers as the principal target in a piece of art. The location of this installation is the Charlestown area in Boston, an area marked by the victims of gang violence and the unsolved cases of the killers; topics that are often ignored in political and social debates. Bunker Hill Monument is a sixty-meter high monolith built to commemorate a battle of the American Revolution, which took place there on the $17^{\text {th }}$ of July 1775 . It is a monument considered as a symbol of local heroic patrimony and national identity. However, the videos projected depict the faces of mothers and brothers while they tell their experiences about losing sons and brothers to gang violence. Specifically, there are five people in the video, three mothers and two brothers, whose testimonies develop an oral history. The people in the video turn the heroic monument into a kind of large character telling the crimes of silent witnesses. It is worth pointing out that these characters hold candles and photographs of the killed relatives at the same time they talk to the camera. Such objects serve as additional registers of memory and as symbols of the very act of remembering and commemorating.

The relatives' voices catch the viewers' attention. In doing so, viewers become second witnesses and carriers of the mnemonic accounts described. During the three nights in which the film is projected, Bunker Hill Monument establishes itself as a means for testimony and a screen for memory.

The original monument was built to represent the target principles in the revolutionary battle for liberty. On the other hand, Wodiczko's projection on this monument claims for the freedom of the victims, their need to be heard and the right of all people to justice. As the artist claims, "this historic monument, dedicated to the heroes of a Revolutionary War battle, becomes a contemporary memorial to the present-day heroes and heroines who continue another battle on the same (sacred) ground. This battle against tyranny and oppression continues 
still, inflicted now by murderous and unpunished urban violence and perpetuated by speechlessness and silence, imposed from without and from within” (1998).

The work Bunker Hill Monument is similar to the project designed for the City Hall Towers in Cracow (1996) and A-Bomb Dome in Hiroshima (1999). Wodiczko's film projections on monuments combine different methods for broadcasting oral history and video media, aiming to give voice to the victims of traumatic events. In the case of the project for the City Hall Towers, the victims are the survivors of domestic violence, people who had never been given the opportunity of telling their memories and traumatic experiences publicly.

In A-Bomb Dome, films are projected on the Genbaku Dome, a well-known building in ruins after the Hiroshima bombing that is now a Peace Memorial. Victims and survivors of the devastating bombing tell their life experiences in the film. Victims not only pass on their memories to the citizens, but also revitalize the mnemonic story of the building itself.

Wodiczko's pieces of art can be understood as genuine acts by which the stories embedded in architecture and monuments are reinstated. Such stories are overlapped with the memories of those people excluded from official accounts on history and past events, providing a new interpretation to the building. Images merge with the surface of the building façade where they are projected, a surface with the marks of the passing of time. The texture of the film changes and integrates the cracks in the façade as a metaphor for the traces created by social segregations.

Wodiczko's pieces of art establish themselves as revisionist works of history that retrieve the stories about experiences disregarded in official accounts to provide them a place in the public realm and the collective consciousness. As a matter of fact, such stories even gain a higher level in comparison to the values and memories represented in the monument.

Monuments are meant to comprehend and generate memory, and film and media fulfil the task of looking at (recording images) and giving visibility (broadcasting images). Wodiczko's projections overlap and merge both assignments. In doing so, the one-direction communication in traditional monuments, by which fixed stories about the past are represented and delivered to the public, now becomes a multi directional act of communication, since the artworks demand the viewer to do a critical reading. It is now the viewer's task to construct the historical and mnemonic account about the events represented in the film installation. In watching the film and reconstructing the mnemonic account, the viewer becomes a secondary witness of the historical event. In Lisa Saltzman's words, “through displacements 
and postponement of projection technology and the temporality of testimony, the projection of the monument video, delayed and with power, offers at the same time that needs to be reproduced, the possibility to bear witness" $(2006,45)$.

Citizens attend a type of visual and audible ceremony that makes them become testimony of the actual witnesses. Viewers morally commit and take the witnesses' stories as their own, due to the empathetic feeling of belonging to the same society and sharing a collective and historical memory that is built up by everyone.

Spectators are key figures in these kind of public artworks, because they are the subjects who need to review history and the past. In doing so, the objective of the artwork is fulfilled. As Suzi Gablik states, ephemeral artworks displayed in a specific location "leave in the spectator a kind of moral echo strange in permanent installations and canalise in the dialogue with the public about certain social issues. The appearances and disappearances make installations more imaginative and seem to come up from the stone in the buildings as secretion, or as a repressed memory or dream" $(1991,102)$.

The ephemeral, immaterial and imaginative features that Gablik refers to are the ones that take us into the realm of memory and its intangible quality, providing the installation with a suggestive characteristic that catches our attention and urges us to mentally retrieve stories of the past.

Wodiczko's installations for specific locations create places of memory where citizens reflect not only on their own history, but also on the mnemonic process by which we construct it.

A work of memory develops during the period of time that the projection remains displayed. In that portion of time, the victims' personal memories become collective memories for the spectators watching the installation and hearing the stories. The artist is an intermediary that reviews history and produces a space that holds the private and the public, memory and history, as well as art and daily life. In Diana Nemiroff's words, "Wodiczko's epic narrative replaces the realism of the production by the realism of representation. It is not only the role of the artist demythologised in this intention, but also the piece of art is redefined as a place for a dialectic interchange, more than economic by nature. Thus, the narrative in the projection fuses with its reception to create a critical model for reinterpreting art in social life" $(1986,26)$.

Ultimately, it is worth pointing out the impact that Wodiczko's art makes in the sphere of public amnesia. His works offer, even if only temporarily, the possibility of representing a part of the history of a community to be remembered and reviewed, and integrate it in the citizens' memory. 


\section{Jane and Louise Wilson and the Use of Temporality}

British twin artists Jane and Louise Wilson (1967, Newcastle) work on art forms such as media, film, photography and installation. Historical memory is a common topic in their artistic career, generally articulated through empty locations, areas that have been evacuated due to war conflicts, as well as ruined, non-functional or abandoned places. Historical memory in the Wilson sisters' works is completed with the experienced histories and memory accounts of citizens of certain events. A common feature of their film works is actors occupying old locations that have important links to historical matters. Such physical occupation suggests a connection between the psychological aspect of people and architecture, taking the viewers to different times and places, normally set between the Second World War and current times. In their works, "there is a need of reflexion about how we relate to memory and recent past, especially with traumatic issues that, as a psychological defence, we urge to forget."

It is worth pointing out some of the Wilson sisters' key pieces of art, such as Hypnotic suggestion 505 (1993), a recording of the old flour factory in Oporto; Gamma (1999), a video installation with several screens recorded in a US military base in Greenham Common (Berkshire), a place used as a warehouse for nuclear missiles during the Cold War; A Free and Anonymous Monument (2003), a film made from images of a microchip factory, children's games, a lake, a rusted petroleum platform and the Apollo Pavilion in Peterlee New Town, near Gateshead; Spiteful of Dream (2008), a film recorded in the community centre of BosniaHerzegovina, with men and women's voices telling their traumatic experiences as emigrants seeking asylum in the United Kingdom; or the photographic series Oddments (2008), about one of the biggest bookshops in London, with a room in which expensive books with front pages missing are stored, something that makes them dysfunctional. Jane and Louise Wilson's long artistic career and specifically these artworks show the artists' commitment to exploring historical memory.

Unfolding the Aryan Papers is a film that links personal and historical memory, reality and fiction, as well as body and space. It is a clear example of a work that uses temporality as a strategy to evoke memory. Temporality means the way we experience time, and it is closely linked to the notion of past, present and future. Through the strategic representation of moments from different times, the artists trigger a memory work in the viewer.

6 Tempo suspenso. Jane \& Louise Wilson, (exhibition catalogue), CGAC, Centro Galego de Arte Contemporánea, Santiago de Compostela, 22. 08. 2010-02. 03. 2011: 3. (Author's translation.) 
It is relevant to elucidate the difference between the notion of time and temporality to clearly understand how they are embedded in contemporary artworks.

The field of time studies is very large, which means that different concepts from different disciplines get blurred into each other to define it, often leading to contradictory understandings of time. Fernand Braudel $(1958,730)$ claimed that, for historians, time is a measure. However, Charles Tilly confronted Braudel's claim with the problem of time as it appears in historical sociology, since it depicts the socio-temporal conditions that underlie events and processes (2001, 570). Paul Ricoeur points out that the meaning of history is a narrative or a story, and therefore, time has a "when" category of meaning in the narrative order and is no longer an external measure, but a cultural dimension (2000, 173). For Niklas Luhmann, time is a symbol that indicates that several things can happen at the same time, and no single action can achieve complete control over the conditions in which it is taking place $(1995,41)$.

In order to analyse the links between film and memory in visual arts, I will employ the notion of time given by Polish sociologist and professor Elżbieta Hałas, which also draws on Luhmann's analysis. According to Hałas, the concept of time relates to a quantity of duration that changes in a uniform and sequential order. Time is, in a sense, empty; without content or meaning beyond its own linear progressing. It is when nothing happens, and goes on not happening (Hałas 2010, 310).

On the other hand, temporality stands for the way in which we undergo and live time. It is a variation of time, which allows us to discern the difference between what already happened and what is about to come. The dimensions that characterize temporality are neither uniform nor predictable. Time can be fulfilled and made anew through a profound change or rupture of some kind, making what happens thereafter radically unlike what had come before (Hałas 2010).

In Elżbieta Hałas's own words, "time is basically given in changes, which may be reversible or irreversible. Of significance for the cultural perspective is precisely the thesis that time - whatever it may be - does not necessarily require irreversibility, which allows us to distinguish between time and temporality. Temporality refers to experiencing and representing time with metaphors which emphasize its irreversibility" $(2010,42)$. More specifically, temporality within culture is the awareness of time passing that materializes in representations and experiences of time.

In Unfolding the Aryan Paper, there are several stories that intersect, stories about subjective and personal memories and also about collective historical 
memory. In order to materialize this project, the Wilson sisters obtained a commission from Animate Projects and the British Film Institute, where they had access to comprehensively research the Stanley Kubrick archives at London College of Communication. Specifically, the artists focused on Kubrick's unfinished project Aryan Papers. Kubrick's film is based on Louis Begley's book Wartime Lies (1991), which deals with the attempts of the Jews to escape from the Warsaw ghetto. The book tells the story of a Polish woman, Tania, and her nephew, who pretended to be a Catholic to escape from the Jews' persecution during the Nazi occupation in Poland. In spite of all the years that took Kubrick to research on such events, and having even chosen the actors and locations, the film was never made. One of the main reasons for Kubrick to cancel the film Aryan Papers was the release of Steven Spielberg's Schindler's List (1993). The release of The Aryan Papers was cancelled because Kubrick and the top brass at Warner Brothers were worried that it would suffer commercially if it appeared after Spielberg's movie.

Besides, as many other post-war artists and after Adorno's statement "to write poetry after Auschwitz is barbaric" (1967), Kubrick faced the challenge of representing or dealing with the unrepresentable, that is, producing images of the terrible sacrilege perpetrated by the Nazis. Kubrick eventually decided to abandon the project, unlike Alain Resnais, who completed the film Night and Fog in 1958. Resnais made this film by putting together appropriated images about the locations where the Holocaust took place and new images recorded by him.

The main concern in Unfolding the Aryan Papers, besides its use (and exploration) of temporality, is exploring the relationship between the body and politicized architecture. The Wilson sisters hired Johanna ter Steege for the film, the actress Kubrick chose as the main actress to take the role of the Jewish woman, Tania.

Johanna ter Steege met with Kubrick several times to plan her role, rehearse some scenes and try some camera shots. In Unfolding the Aryan Papers, Tania acts the role that Kubrick planned for the actress. She re-enacts the rehearsals and scenes that they shot, reconstructs her own memories and actions and poses in front of fascist neoclassic architecture wearing thirty different dresses that were to be worn in the film. Staring at a point out of the shot frame, Johanna retrieves her memories of what was an important time in her professional career, and she later tells in voice-over the details of the meetings with Kubrick. Her words are full of emotions as they go from an initial excitement to an eventual disappointment when the project fails. The actress's personal memories mix with the dialogue in the original plot in Aryan Papers, in which Tania talks about her German love and 
their plans to leave the country. The Wilson sisters deal with the Holocaust in an indirect approach, refusing a mimetic representation or referring to the specific events that took place. In doing so, they express what really defines the Holocaust and its memory: the impossibility of being represented. As Louise Wilson states: "I think the film shows just the impossibility of representing something like the Holocaust, which is exactly what Kubrick struggled with and what made him feel overwhelmed in terms of what he could have created as a director" $(2011,143)$.

The figure of the main actress works as a central element in the Wilson sisters' film and symbolizes the dialectics between her role as an actress and the affective or emotional features as an individual, who remembers the past. The different temporalities help construct the plot and trigger a memory work on the viewer. Metaphorically, the film develops a document for history and a piece of fiction through film; it unfolds in a comparison between fact and theatre. Unfolding the Aryan Papers rejects a direct representation of Holocaust by using images of the events and aims to tackle that period of time through Steege's personal story, even if not leaving aside the appraisal of Kubrick's productions and his legacy in present times.

Historical and personal memory, what can and can't be represented, the absence and the presence, trauma and affective emotions, fictive accounts and personal accounts merge in the medium of art. These topics are contentious but can be handled effectively in visual art, since it is a suitable site to hold metaphoric messages. The Wilson sisters "have demonstrated that they belong to a privileged generation to counter Adorno's declared silence about the debatable possibility of the barbaric. This fact is not based in a modernist perception as an open process but as a position that accepts doubts, instability of senses and the ability of visual art to positively construct other accounts to commemorate the past."7

\section{Conclusion}

The works by artists Tacita Dean, Krzysztof Wodiczko and Jane and Louise Wilson are representative of the development of what Susannah Radstone calls memorywork, a process of involvement with the past that has both an ethical and historic aspect (Radstone 2000, 11-13).

The different uses of film in contemporary art, proposing the contrast between analogue and digital platforms, as well as going beyond the limited spaces of

7 Tempo suspenso. Jane \& Louise Wilson, (exhibition catalogue), CGAC, Centro Galego de Arte Contemporánea, Santiago de Compostela, 22.08.2010 - 02.03.2011: 3. (Author's translation.) 
galleries and museums, make the viewer aware of the ever-evolving ways in which we record, document and broadcast our everyday life and the past, as well as the large impact that images have on memory processes (remembering, commemorating, recording events, etc.).

Films and video artworks dealing with memory show that culture is characterized by what Mieke Bal called acts of memory (Bal 1999). They are not just representations of the past in the present, but rather an interpretation of the influence of such past events from a current perspective. It is an act to activate and give sense to past experiences and events, paying particular attention to the shape they take in the present. As Mieke Bal states, "cultural recall is not only something you have by chance, but something you perform, even if in many cases, such acts are not consciously conceived" (1999, VII).

Memory works and acts of memory are materialized in all types of objects and images from the past. And that's why film and video artworks are an ideal site, through which visual strategies can be developed to help memory be broadcasted, represented and shared.

The analysis of Dean's, Wodiczko's and the Wilson sisters' artworks demonstrate that some features of film and video make them an ideal medium to represent memory and trigger a memory work in the viewer. Dean focuses on the aesthetics of analogue film and records abandoned places as a strategy to make the viewer recall the past and historical events. Wodiczko uses film to retrieve the testimonies of the victims from the past and selects specific monuments and buildings (carriers of historical, political and social connotations) as the screen to create a dialogue between architecture and film. Such strategy enables a critical revision of past and historical events.

Time and temporality are features of film and video that become the key strategy in Jane and Louise Wilson's works, and are utilized as a means to catch the spectator's attention. In doing so, the Wilson sisters' films not only echo the way in which memory works, but it also evokes different events in the past in a non-lineal sequence.

Contemporary art dealing with memory has executed a distinguished role in the retrieval, reinterpretation and representation of the past. In this way, it has become a quasi-archetypal medium to demonstrate the importance of memory in current times both for life and for contemporary culture. Contemporary art, in its commitment with history and society, has demonstrated itself to be a fruitful means to investigate the meaning of memory, history and temporality in contemporary culture. Eventually, the primary goal in Dean's, Wodiczko's and 
Jane and Louise Wilson's works is not to restore an event from the past, but to retrieve it and confirm memory as a cultural, anthropological and existential fact. Their works bring the past closer to the present, so that the recalled past might disclose what was otherwise forgotten, unseen, or unrealized.

\section{References}

Adorno, Theodor W. 1967 [1955]. Prisms. London: Neville Spearman.

Assmann, Jan. 1992. Cultural Memory: Writing, Memory and Political Identity in Early Civilizations. Munich: Verlag C. H. Beck.

Bal, Mieke; Jonathan Crewe and Leo Spitzer, eds. 1999. Acts of Memory: Cultural Recall in the Present. Hanover: Dartmouth College, University Press of New England.

Braudel, Fernand. 1958. Histoire et science sociales: La Longue durée. [History and the Social Sciences: The Long Durée], Annales ESC 4: 725-753.

Segesten, Dutceac A. and Jenny Wüstenberg. 2016. Memory Studies: The State of an Emergent Field. Memory Studies. ePub. June 20.

Foucault, Michel. 1977. Language, Counter-Memory, Practice. Ithaca, New York: Cornell University Press.

Gablik, Suzi. 1991. Making Art as if the World Mattered. Models of Partnership. In The Reenchantment of Art. New York: Thames and Hudson.

Gibbons, Joan. 2007. Contemporary Art and Memory: Images of Recollection and Remembrance. London; New York: I. B. Tauris.

Halbwachs, Maurice. 1950. La mémoire collective. Paris: Albin Michel.

Hałas, Elżbieta. 2010. Time and Memory: A Cultural Perspective. Trames vol. 14 (64/59), no. 4. Warsaw: University of Warsaw.

Huyssen, Andreas. 1995. Twilight Memories: Making Time in a Culture of Amnesia. London: Routledge.

Landsberg, A. 1995. Prosthetic Memory: Total Recall and Blade Runner. Body $\&$ Society vol. 1, no. 3-4: 175-189.

Luhmann, Niklas. 1995. Social Systems. Stanford, CA: Stanford University Press.

Nemiroff, Diana. 1986. Canada, XLII Biennale di Venezia. Ottawa: National Gallery of Canada.

Radstone, Susannah. 2000. Memory and Methodology. Oxford and New York: Berg.

Ricoeur, Paul. 2000. La mémoire, l'histoire, l'oubli. [Memory, History, Forgetting], Paris: Éditions du Seuil. 
Royoux, Jean; Marina Warner and Germaine Greer. 2006. Tacita Dean. London: Phaidon.

Saltzman, Lisa. 2006. Making Memory Matter: Strategies of Remembrance in Contemporary Art. Chicago: University of Chicago Press.

Tilly, Charles. 2001. Historical Analysis of Political Processes. In Handbook of Sociological Theory, ed. Jonathan H. Turner, 567-588. New York: Kluwer Academic.

Trodd, Tamara. 2008. Lack of Fit: Tacita Dean, Modernism and the Sculptural Film. Art History vol. 31, no 3, June: 368-386.

Wodiczko, Krzysztof. 1998. Artist's Statement. Assemblage: A Critical Journal of Architecture and Design Culture no. 37, December: 7-21.

Wodiczko, Krzysztof. 1999. Critical Vehicles: Writings, Projects, Interviews. Cambridge, MA: The MIT Press. 